\title{
Secukinumab-induced Oral Lichen Planus: A Report of Case and Review of Literature
}

\author{
Sekukinumab İlişkili Oral Liken Planus: Bir Olgu Sunumu ve Literatürün Gözden \\ Geçirilmesi
}

(1) Munise Daye1, (D) Selami Aykut Temiz², (1) Selim Gümüș1, (1) Fahriye Kılınç3

${ }^{1}$ Necmettin Erbakan University, Meram Faculty of Medicine, Department of Dermatology, Konya, Turkey

2Konya Ereğli State Hospital, Clinic of Dermatology, Konya, Turkey

${ }^{3}$ Necmettin Erbakan University, Meram Faculty of Medicine, Department of Pathology, Konya, Turkey

\begin{abstract}
Recent years, we are witnessing a more frequent use of biological agent treatments. Secukinumab (SEC) has been used successfully in the management of psoriasis, psoriatic arthritis, and ankylosing spondylitis. However, the cases of SEC-related lichen planus (LP) are rarely encountered in the literature. Herein, this report presents a case of oral LP induced by SEC in a 33-year-old patient with psoriasis. In addition, this report aims to review the lichen reactions associated with SEC in the literature. In conclusion, LP cases attributable to SEC use are increasingly being observed in new reports. Clinicians who use SEC in their patients should be aware of this side effect and observe patients in terms of cutaneous-mucosal LP. With the introduction of new interleukin-17 (IL-17) inhibitors, the reporting of side effects is crucial for learning whether LP is class side effects or drug-specific side effects for clarifying pathogenesis. Dermatologists and rheumatologists should be aware of the very rare negative effect of IL-17 inhibitors.
\end{abstract}

Keywords: Secukinumab, IL-17 inhibitors, lichen planus, psoriasis

\section{ÖZ}

Biyolojik ajan tedavileri son yıllarda artan sıklıkta kullanılmaktadır. Sekukinumab (SEK) sedef hastalığı, psoriatik artrit ve ankilozan spondilitte başarıyla kullanılmaktadır. Sekukinumab ile ilișkili liken planus (LP) olgularına literatürde nadiren rastlanmaktadır. Burada, sedef hastalığı olan 33 yaşında bir kadında sekukinumab ile indüklenen oral LP olgusunu sunuyoruz. Ek olarak literatürdeki sekukinumab ile ilișkili liken reaksiyonlarını da gözden geçirmeyi amaçladık. Sonuç olarak, SEK kullanımına bağlı LP olguları yeni raporlarla artmaktadır. Hastalarında SEK kullanan klinisyenler bu yan etkinin farkında olmalı ve hastalarını kutanöz ve mukozal LP açısından gözlemlemelidir. Yeni interlökin-17 (IL-17) inhibitörlerinin kullanılmaya başlanmasıyla, LP yan etkisinin sınıf yan etkileri mi yoksa ilaca özgü yan etkiler mi olduğunu ve patogenezi açıklığa kavuşturmak için yan etkilerin raporlanması önemlidir. Dermatologlar ve romatologlar IL17 inhibitörlerinin çok nadir olumsuz etkilerinin farkında olmalıdır.

Anahtar Kelimeler: Sekukinumab, IL-17 inhibitörleri, liken planus, psoriazis

\section{Introduction}

Paradoxical drug reactions are unexpected drug reactions. Paradoxical psoriasis is the most common paradoxical reaction during tumor necrosis factor-alpha treatment, which is one of the biological agent treatments (1). There has been an increasing use of biological agent treatments in recent years. Secukinumab (SEC) has been used successfully in the management of psoriasis, psoriatic arthritis, and ankylosing spondylitis (2). However, the cases of SEC-related lichen planus (LP) are rarely encountered in the literature (3-7).
Herein, this report presents a case of SEC-induced oral LP in a 33-yearold woman with psoriasis. In addition, this report aims to review the lichen reactions associated with SEC in the literature. Dermatologists and rheumatologists should be aware of the very rare negative effect of interleukin-17A (IL-17A) inhibitor SEC.

\section{Case Report}

SEC treatment was initiated in a 33-year-old patient who was followed up with psoriasis and previously received methotrexate, cyclosporine, and narrow-band ultraviolet B phototherapy treatments. In this SEC-

Cite this article as/Atıf: Daye M, Temiz SA, Gümüş S, Kılınç F. Secukinumab-Induced Oral Lichen Planus: A Report of Case and Review of Literature. İstanbul Med J 2021; 22(3): 235-7.

(C) Copyright 2021 by the University of Health Sciences Turkey, Istanbul Training and Research Hospital/istanbul Medical Journal published by Galenos Publishing House.

(C) Telif Hakkı 2021 Sağlık Bilimleri Üniversitesi Istanbul Ĕgitim ve Araştırma Hastanesi/Istanbul Tıp Dergisi, Galenos Yayınevi tarafından basılmıștır. 
treated case for about three months, psoriasis area severity index 100 was reached. The patient had no other disease than psoriasis. Moreover, there was no other drug use other than SEC.

In the third month of treatment, reticular plaques appeared in the buccal area on the oral mucosa of the patient (Figure 1). Biopsy and direct immunofluorescence were performed from the oral mucosa of the case with the preliminary diagnosis of LP and pemphigus vulgaris. In the laboratory parameters, normal or negative were the remaining peripheral blood count, C-reactive protein, liver enzyme, creatinine, antinuclear antibody, U1RNP, Sm, Ro, La, SCL-70, CENP, Jo- 1, dsDNA, and PmScl. The histopathology revealed band-like lichenoid infiltration and basal vacuolar changes (Figure 2). Direct immunofluorescence examination was negative. Oral LP was diagnosed clinically and histopathologically. The evaluation of Naranjo adverse drug reaction (ADR) probability scale revealed that the case had 6 points $(6 / 10$; probable ADR). The final diagnosis was a paradoxical drug reaction with SEC-induced oral LP. SEC was not discontinued because the reaction was not life-threatening. Oral lichen was controlled with topical corticosteroid treatment. In the follow-up of the patient for six months, the lesions have remained stable and the follow-up was continued. Informed consent was obtained from the patient for the publication of this case report and images.

\section{Discussion}

IL-17A is a cytokine that is believed to play a key role in the pathogenesis of psoriasis (8). SEC is a fully humanized anti-IL-17A monoclonal

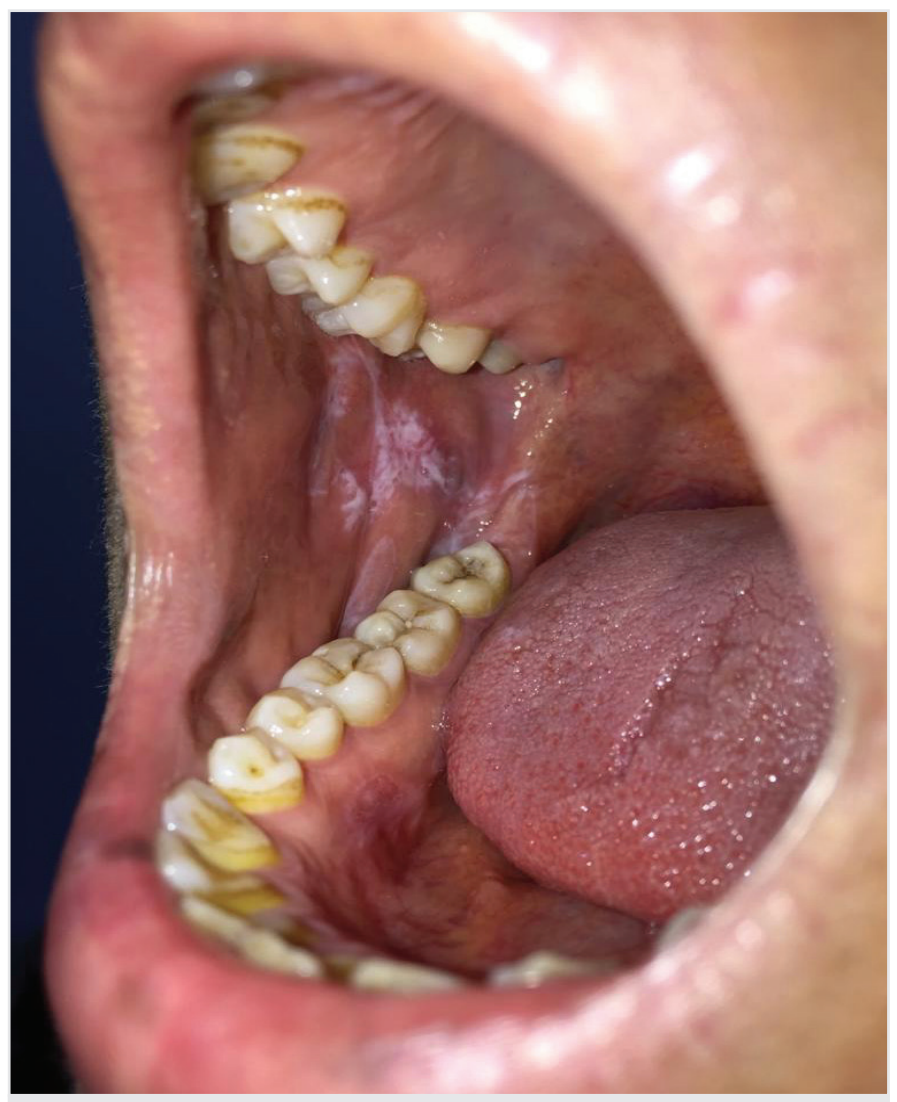

Figure 1. Reticular plaques on the right buccal area antibody. Many cutaneous side effects of SEC, including LP/lichenoid reactions (LR), have been reported previously (9). In the literature, we have determined five case reports for SEC-related LP (3-7). Our case was the youngest patient among them.

Although Doolan et al.'s (3) case did not have oral mucosal involvement, all others had involvement of oral mucosa (4-7). Maglie et al.'s (7) case had both oral mucosa and trunk involvement. In our case, only oral mucosal involvement was present. LP/LR lesions occurred in patients from 1 week to 8 months after the onset of SEC treatment in the literature. In our case, lichen lesions developed in the third month of treatment. Treatment was discontinued in four patients (4-7) who developed a SEC-related reaction; in one of them, SEC administration was changed to that of Ixekizumab (5). In our case, as in Doolan et al. (3), SEC treatment was not stopped because the lesions were stable. In patients who were discontinued SEC, there was an improvement in lesions between four weeks and eight weeks (4-7). In our case, who SEC treatment was not ceased, the lesions did not recover completely, but remained stable, similar to the case of Doolan et al. (3).

The literature reported two cases of concomitant oral candidiasis cases $(5,6)$. Histopathology was performed in four of five patients, and one case was diagnosed clinically and dermoscopically. Histopathology was compatible with LP in two patients and with LM in two patients. Our case was histopathologically compatible with LP and no simultaneous candida was detected. Table 1 shows detailed information about all the cases reported in the literature along with our case.

Several hypotheses have been proposed to explain the LP side effects of SEC. SEC may trigger oral LP development by causing oral candidiasis (6). Another factor is dendritic cell upregulation and an increase of type I interferon (IFN) after IL-17 neutralization (3). An obvious increase in plasmacytoid dendritic cells and IFN in cutaneous and oral lesions in LP also supports this result (10). However, it is not clear how the reaction was triggered.

Thompson et al. (4) believed that oral LR were the class side effects of IL-17 blockers. However, Capusan et al. (5) believed that this was a drug-specific side effect rather than a class side effect because the same side effects are not observed after switching to Ixekizumab. More case reports and observations are needed to clarify this situation.

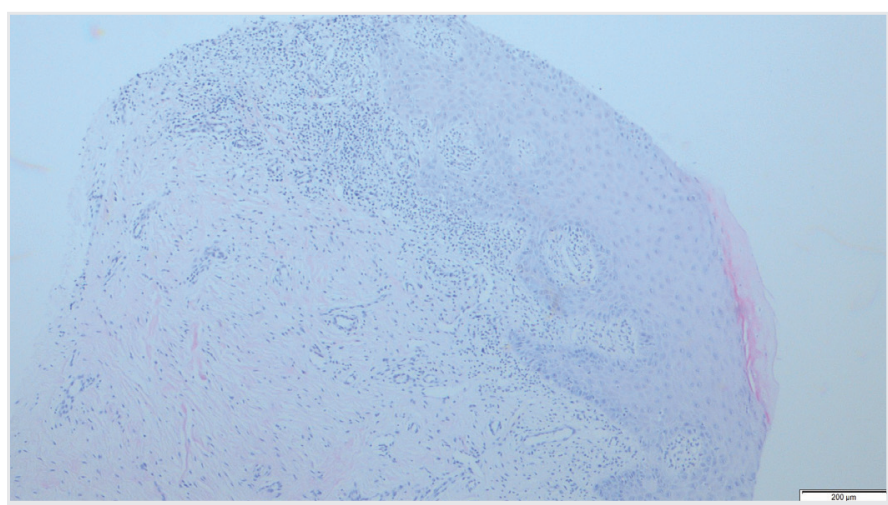

Figure 2. The band-like lichenoid infiltration and basal vacuolar changes in the histopathology (hematoxylin and eosin, $\mathrm{x} 40$ ) 
Table 1. Literature data to date about the LP/LM due to secukinumab use

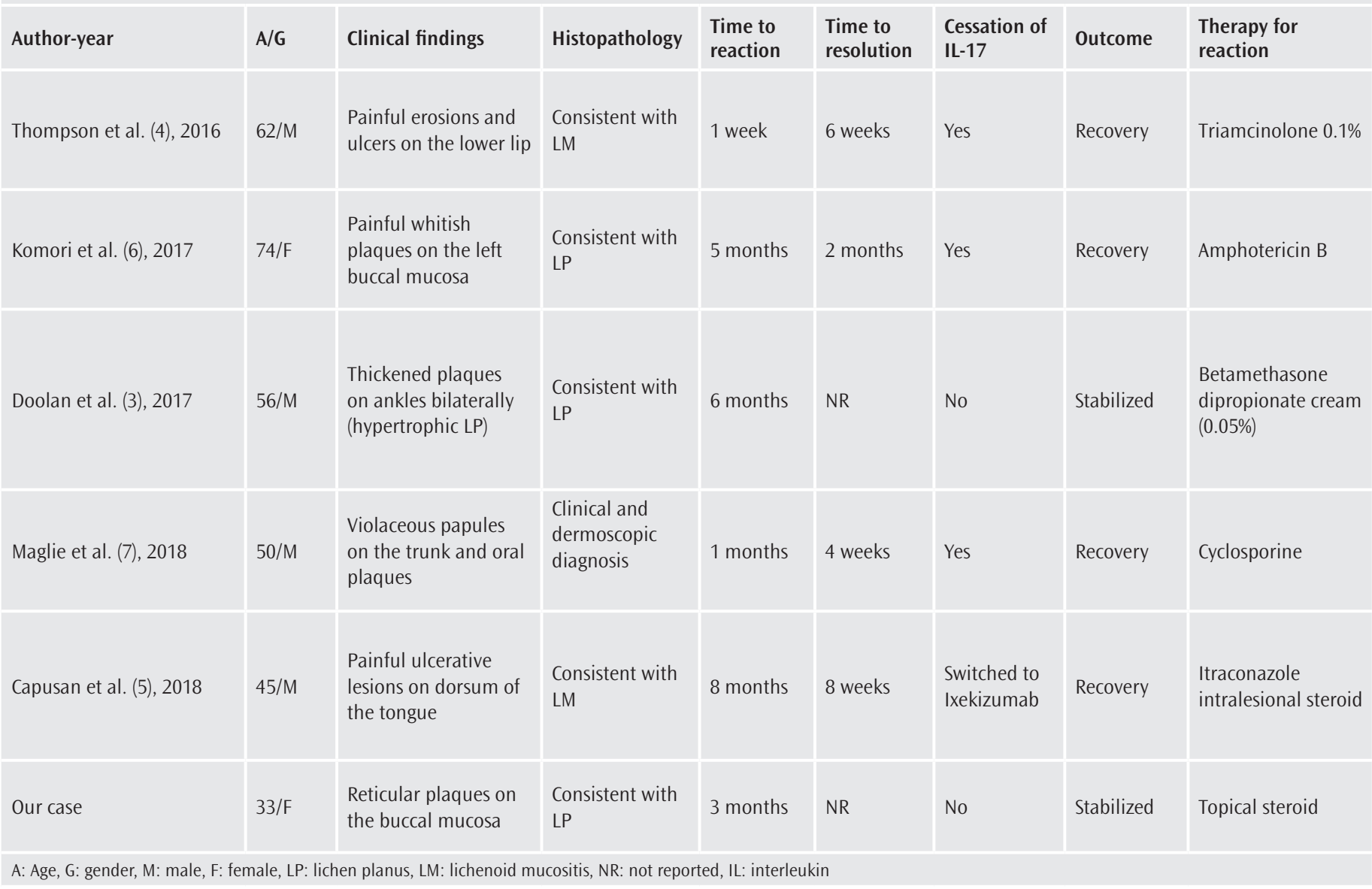

LP and LR cases attributable to SEC use are increasingly being observed in new reports. Clinicians who use SEC in their patients should be aware of this side effect and observe patients in terms of cutaneous-mucosal LP. With the introduction of new IL-17 blockers, the reporting of side effects is important for learning whether LP and LR are class side effects or drug-specific side effects and clarifying pathogenesis.

\section{Ethics}

Informed Consent: Informed consent was obtained from the patient for the publication of this case report and images.

Peer-review: Externally peer-reviewed.

Authorship Contributions: Surgical and Medical Practices - M.D., S.A.T.; Concept - M.D., S.A.T.; Design - M.D., S.A.T.; Data Collection or Processing - M.D., S.A.T., S.G., F.K.; Analysis or Interpretation - M.D., S.A.T., S.G., F.K.; Literature Search - S.A.T., S.G.; Writing - M.D., S.A.T., S.G.

Conflict of Interest: No conflict of interest was declared by the authors.

Financial Disclosure: The authors declared that this study received no financial support.

\section{References}

1. Durmaz K, Ataseven A, Ozer I. Paradoxical plaque psoriasis due to secukinumab treatment in an ankylosing spondylitis patient. Dermatol Ther 2020; 33: e13504.
2. Ataseven A, Temiz SA, Eren G, Özer I, Dursun R. Comparison of anti-TNF and IL-inhibitors treatments in patients with psoriasis in terms of response to routine laboratory parameter dynamics. J Dermatolog Treat 2020;1-6.

3. Doolan BJ, Anderton H, Christie M, Dolianitis C. Cutaneous lichen planus induced by secukinumab. J Clin Exp Dermatol Res 2017; 9: 1 .

4. Thompson JM, Cohen LM, Yang CS, Kroumpouzos G. Severe, ulcerative, lichenoid mucositis associated with secukinumab. JAAD Case Rep 2016; 2: 384-6.

5. Capusan TM, Herrero-Moyano M, Martínez-Mera CR, Freih-Fraih AW, Dauden E. Oral lichenoid reaction in a psoriatic patient treated with secukinumab: A drug-related rather than a class-related adverse event?. JAAD Case Rep 2018; 4: 521-3.

6. Komori T, Honda T, Endo Y, Kaku Y, Otsuka A, Kabashima K. Oral lichen planus associated with candidiasis during secukinumab treatment. J Dermatol 2017; 44: e60-1.

7. Maglie R, Di Cesare A, Lazzeri L, Pescitelli L, Ricceri F, Vannucchi, M, et al. Lichen planus triggered by CT-P13 and recurrence during secukinumab treatment. Br J Dermatol 2018; 178: 303-4.

8. Langley RG, Elewski BE, Lebwohl M, Reich K, Griffiths CE, Papp K, et al. Secukinumab in plaque psoriasis--results of two phase 3 trials. N Engl J Med 2014; 371: 326-38.

9. Blackcloud P, Dupuy E, Kang Y, Smart C, Hsiao J. Bullous acral eruption related to secukinumab. Dermatol Online J 2019; 25: 13030/qt9q7937xb.

10. De Vries HJ, van Marle J, Teunissen MB, Picavet D, Zorgdrager F, Bos JD, et al. Lichen planus is associated with human herpesvirus type 7 replication and infiltration of plasmacytoid dendritic cells. Br J Dermatol 2006; 154: 361-4. 